\title{
Observații asupra conținutului lexical la începuturile semanticii structurale
}

\author{
Dinu Moscal ${ }^{*}$ \\ Institutul de Filologie Română „A. Philippide”, Str. Th. Codrescu 2, 700481 Iași, România
}

\section{Despre articol}

Istoric:

Primit 11 aprilie 2019

Acceptat 16 aprilie 2019

Publicat 7 mai 2019

Cuvinte-cheie:

semantică

structuralism

lexicologie

cîmp lexical

diacronie

\begin{abstract}
Rezumat
În contribuția de față sînt evidențiate dificultăţile semnalate de cîțiva lexicologi germani din perioada de început a semanticii structurale, în demersul lor de a identifica o posibilă organizare a lexicului unei limbi. Studiile acestora, începînd cu Jost Trier, s-au axat pe analiza unor grupuri lexicale, numite „cîmpuri lexicale” (germ. Wortfelder), considerate a fi părți ale unui lexic complet organizat. Percepția lor idealistă—conform căreia întregul lexic al unei limbi are o organizare ce trebuie doar descoperită —a fost pusă în faţa unor probleme majore. O observație cu relevanță la nivel general și bazată pe exemplificări concrete din lexic pune în evidență faptul că există cuvinte care nu pot fi încadrate într-un cîmp lexical. $\mathrm{O}$ altă observație vizează imaginea de continuum semantic a cîmpului lexical, comparat în unele lucrări cu imaginea unui mozaic. Aceste probleme sînt discutate în cadrul argumentaţiei date de autorii din epoca respectivă, ale căror cercetări se bazau pe o analiză diacronică a lexicului. Observațiile critice din această perioadă au fost fructificate în faza a doua a teoretizării cîmpurilor lexicale.
\end{abstract}

\section{Introducere}

Orice activitate cognitivă a omului presupune întîi identificarea obiectului (care poate fi mai mult sau mai puțin clară) și apoi identificarea părților ce constituie obiectul supus cunoașterii. În cazul limbajului verbal, se consideră, în principiu, că elementele constitutive sînt cuvintele, chiar dacă vechii indieni au identificat cu atît de mult timp în urmă valoarea morfemelor. Cuvintele privite ca elemente constitutive ale limbii prezintă o problematică asemănătoare cu însăşi limba, atît timp cît sînt privite ca individualități, adică fără luarea în considerare a planului funcționării lor. Una dintre problemele comune ambelor niveluri-al limbii și al elementelor constitutive ale limbii, cuvintele-o constituie raportul cu realităţile desemnate și cu conceptele ce corespund acestor realităţi. Încercarea de a stabili natura acestui raport a întîmpinat dificultăți atît în abordările filozofice, cît și în cele strict lingvistice.

Problematica raportului cuvintelor cu realitatea desemnată (cu o primă concretizare în întrebarea privitoare la „dreapta denumire lucrurilor” la vechii greci) poate fi considerată încă actuală la nivelul de analiză al elementelor constitutive, în special în privința definirii cuvintelor onomatopeice (cînd nu se are în vedere că și acestea au la bază o convenție). Raportul cu nivelul conceptual, ale cărui începuturi pot fi identificate în observațiile făcute de Locke (1961) în privința intelectului omenesc, este pus în evidență de Humboldt (2003) și aplicat în studiile lexicologilor germani de la mijlocul secolului trecut, în special de către Weisgerber (1973, p. 196), care pune în circulație conceptul de 'lume intermediară, germ. Zwischenwelt. În privința nivelului conceptual este necesară o clarificare preliminară. Nivelul conceptual nu trebuie să se confunde cu realităţile intelectuale (ale gîndirii sau ale imaginației) sau psihice (emoționale), deoarece și ele au o reprezentare conceptuală. Spre exemplu, cuvîntului patriotism îi corespund diverse realități (gîndite în funcție de epocă și mediu cultural), însă conceptul este unul simplificat, o schemă a acestei realități, care ar putea fi readată prin „iubire față de patrie” (fără detalii în privința modului în

\footnotetext{
*Adresă de corespondență: dinu.moscal@gmail.com.
} 
care se manifestă aceasta). O realitate psihică precum sentimentul de ură este desemnat în limba română prin cuvîntul ură, căruia îi corespunde un concept simplificat („sentiment de aversiune față de cineva sau ceva"), însă realitatea sentimentului este ceva complex și diferit de la o persoană la alta. Analizarea acestor raporturi la nivelul general al limbajului verbal revine cercetărilor filozofice sau de filozofie a limbajului. În privința celui de-al doilea nivel—cel al cuvintelor privite ca unități în afara planului funcționării-, aceste raporturi au fost avute în vedere în cercetările dedicate limbii încă înainte de apariția lingvisticii ca știință, în special în cercetările etimologice, la care se adaugă, mai tîrziu, cercetările de semantică.

Obiectivul prezentei contribuții se delimitează de primul nivel, așadar are în vedere analiza statutului cuvintelor în raport cu realitatea desemnată și cu conceptele corespondente acesteia. Perioada de referință este a doua treime a secolului trecut, cînd lexicologia germană a fost marcată de o serie de contribuții de înalt nivel privind conceptul de 'cîmp lexical'. Unul dintre aspectele mult discutate și criticate ale teoriei este cel legat de gradul de suprapunere dintre o arie conceptuală și aria semantică corespondentă (formată din conceptele ce pot fi încadrate într-un concept mai larg sau într-un domeniu relativ limitat), reprezentată la nivelul lexicului printr-un cîmp lexical. În această primă fază a teoriilor despre cîmpul lexical, se considera că întregul lexic al unei limbi este organizat în cîmpuri lexicale, lingviștii trebuind doar să descopere diversele tipuri de structuri ale acestor cîmpuri. Analiza gradului de suprapunere a ariei semantice cu cea conceptuală presupune luarea în considerare nu numai a limitelor ariei semantice, ci şi a continuității (sau a discontinuităţii) acesteia. Astfel, acest din urmă aspect devine o problematică a delimitării semantice a cuvintelor privite ca realități discrete (definite prin raportare la cuvintele cu care împart o semnificație comună), așa cum sînt, de altfel, toate realitățile de ordin cultural. Obiectivul prezentei contribuții este punerea în evidență a contribuțiilor din a doua treime a secolului al XX-lea în elaborarea unei semantici lexicale cît mai adecvate obiectului supus cercetării. Analiza observațiilor critice din această perioadă cu privire la conceptul de 'cîmp lexical' și asimilarea acestor observații în perioada ulterioară probează meritele reprezentanților perioadei de început a semanticii structurale.

\section{Cadru istoric}

Conceptul de 'cîmp lexical' apare sub diferite accepții și denumiri înainte de constituirea semanticii structurale, însă contribuția de bază a studiilor pe această temă este descoperirea unei tipologii a /modului în care termenii care alcătuiesc un cîmp onomasiologic se află în raport unul faţă de celălalt și își delimitează în mod reciproc conținutul. Teoriile pornesc de la o imagine generală asupra limbii, imagine despre care vorbește Humboldt (2003, p. 335):

Man kann die Sprache mit einem ungeheuren Gewebe vergleichen, in dem jeder Theil mit dem andren und alle mit dem Ganzen in mehr oder weniger deutlich erkennbaren Zusammenhange stehen. ${ }^{2}$ / Limba poate fi comparată cu o imensă țesătură în care fiecare parte este legată de alta și toate împreună sînt legate cu ansamblul, într-o rețea mai mult sau mai puțin clar recognoscibilă. (Humboldt (2008), p. 104-105)

Delimitarea unor grupe de cuvinte pe baza semnificaţiei lor comune este un pas important în studiul lexicului, deoarece definiția lexicografică ar putea depăşi o definiție strict descriptivă şi ar putea indica și raporturile în care se află cu cuvintele cu care împarte o arie de semnificație comună. În definitiv, un adevăr comun acceptat în cazul limbii (valabil în cazul tuturor realităţilor culturale) este că entităţile sale nu au un caracter concret, ci unul discret (trăsătură care trebuie pusă în raport direct cu conceptul saussurean de 'valoare'). Caracteristica acestor demersuri este axarea pe organizarea lexicului unei limbi în cîmpuri-delimitate prin metoda onomasiologică—și pe descoperirea unei tipologii a organizării interne

\footnotetext{
${ }^{1}$ În prezentul articol sînt reluate probleme dezbătute în Moscal (2013, p. 38-84).

2̂̂n citat se păstrează ortografia din textul original („man” pentru „mann”, „andren” pentru „,anderen” și „,Theil” pentru "Teil”).
} 
a cîmpurilor, ceea ce a evidențiat dificultățile de natură semasiologică. Descrierea internă a unui cîmp are la bază diferențele care apar în planul diacronic, conform motodei elaborate de Trier (1973), prin care se demonstrează existența unei interdependențe a elementelor din interiorul unui cîmp lexical.

\section{Aria semantică la nivelul cîmpurilor lexicale și conținutul semantic al cuvintelor}

Una dintre caracteristicile de bază ale teoriei cîmpurilor lexicale din această fază este convingerea că există o acoperire completă a ariei semantice corespondente, fapt asupra căruia atrage atenția Kandler (1973, p. 352):

Dieses Theorem der Lückenlösigkeit spielt in der Theorie des sprachlichen Feldes und der damit verbundenen Sprachteorie eine wesentliche Rolle [Această teoremă a lipsei golurilor joacă un rol esențial în teoria cîmpurilor lexicale și a teoriilor despre limbă legate de aceasta].

Urmărind originile teoretice ale conceptului de 'cîmp lexical', se observă că această trăsătură provine din calchierea teoretică a imaginii despre limbă de la Humboldt, care considera că limba ca întreg este o contraimagine a lumii conceptuale. Trier (1934, p. 429, vezi infra) preia această concepție-corectă, dacă este aplicată la planul general al limbii-și o transferă asupra lexicului, considerînd că acesta din urmă se constituie dintr-o rețea de cîmpuri lexicale. Trecerea în plan teoretic a imaginii despre limbă de la Humboldt apare și la Saussure, care propune conceptul de 'familie asociativă’3, fără a se avea în vedere însă limitarea asocierilor numai la un anumit tip, așa cum încearcă să demonstreze Trier. Chiar și în cazul în care s-ar considera că limba este o reprezentare completă a realității conceptuale, acest fapt nu ar însemna că această reprezentare se situează la nivelul lexicului. Realitatea conceptuală îi este accesibilă limbii, însă nimic nu îi impune acesteia să fie simetrică realității conceptuale în ceea ce privește forma expresiei (vezi Hjelmslev, 1967, p. 115). Bloomfield (2005, p. 278) a exprimat foarte clar acest lucru:

What one language expresses by a single morpheme will in another language require perhaps a long phrase; what one language says in a word may appear in another language as a phrase or as an affix [Ceea ce o limbă exprimă printr-un singur morfem poate să necesite o frază lungă într-o altă limbă, ceea ce o limbă spune printr-un cuvînt poate să apară într-o altă limbă ca o frază sau ca un afix].

Această constatare privind nivelul formei expresiei limbii arată că un „bloc conceptual” ${ }^{4}$ poate fi articulat prin limbă la nivelul expresiei fără ca aceasta să se situeze exclusiv în planul lexical și că unele concepte sînt redate cel puțin prin sintagme sau perifraze. De exemplu, conceptul de 'pantof cu toc înalt' are un termen corespondent la nivel lexical în limba germană, și anume Stöckelschuh, care intră în componența cîmpului lexical „(die) Schuche” 'încălțăminte;, dar nu are un termen corespondent la nivel lexical în limba română, unde este exprimat prin sintagma „pantof cu toc înalt”, prin urmare, nu intră în componența cîmpului lexical ,încălțăminte”. Nu este nevoie însă de existența într-o altă limbă a unei echivalențe lexicale pentru a identifica un concept neexprimat printr-un singur lexem într-o anumită limbă. Unele concepte, în special cele care corespund realității gîndite sau imaginate, nu se reflectă în planul lexical al unei limbi, motiv pentru care ideea lui Trier despre cîmpurile care au o structură completă și compactă poate fi pusă sub semnul întrebării. Weisgerber (1962, p. 205-242) a dat deja un indiciu în acest sens, prin prezentarea

\footnotetext{
${ }^{3}$ „Un terme donné est comme le centre d’une constellation, le point où convergent d'autres termes coordonnés, dont la somme est indéfinie”. (Saussure, 1922, p. 174) / „Un termen dat este precum centrul unei constelații, punctul unde converg alți termeni coordonați, a căror sumă este nedefinită”. (Saussure, 1998, p. 138)

${ }^{4}$ „[Das Wortfeld] ist also die äussere, zeichenhafte Seite der begrifflichen Aufteilung, die jener Begriffskomplex, Begriffsblock, Begriffsbezirk durch und für die Sprachgemeinschaft erfährt” [„[Cîmpul lexical] este așadar latura externă, cu caracter de semn, a distribuției conceptuale care rezultă pentru acel complex conceptual, bloc conceptual, acea sferă conceptuală prin și pentru comunitatea lingvistică”]. (Trier, 1973, p. 1)
} 
cazurilor speciale în care este dificil de delimitat conținutul semantic al unor cuvinte, deci și așezarea lor în cîmpuri: cuvintele onomatopeice semiabstracte (germ. brüllen [a rage], brummen [a mormăi]), cuvintele „afective” (germ. Heimat [patrie], Geist [spirit]), creațiile idiolectale sau poetice.

O observație critică directă asupra organizării interne a unui cîmp este cea a lui Reuning (1973, p. 256 257): „Trier glaubt nicht an die «Diskontinuität der sprachlichen Welt», und er versichert uns, zumindest in seiner Theorie, dass das Feld «lückenlos» ist” [„Trier nu ia deloc în calcul «discontinuitatea realității lingvistice» și ne asigură, cel puțin în teorie, că un cîmp «nu prezintă goluri»”] ${ }^{5}$. Reuning aduce argumente chiar din exemplele date de Trier în privința cîmpului pentru domeniul conoașterii (germ. Verstand) analizat în evoluția limbii germane, unde se observă că prin trecerile de la o stare a alta apar și dispar cuvinte pentru unele noțiuni ce aparțin acestui domeniu conceptual. Reuning se referă la observația lui Trier referitoare la lipsa unui cuvînt în germana veche pentru conceptul de 'inteligență pură’:

Der reine Klugheitsbereich hat keine eigenen Worte. Die wachsen ihm mit klug und gescheit erst im 14. Jahrhundert zu [Domeniul inteligenței pure nu avea cuvinte specifice. Acestea au început să se înmulțească abia în secolul al XIV-lea prin klug și gescheit]. (Reuning, 1973, p. 257)

La acest exemplu Reuning mai adaugă un comentariu al lui Schopenhauer privitor la găsirea unui echivalent în limba germană pentru gr. sophrosyne:

Daher also muss man, bei Erlernung einer fremden Sprache, mehrere ganz neue Sphären von Begriffen in seinem Geiste abstecken: mithin entstehen Begriffssphären, wo noch keine waren. Man erlernt also nicht bloss Worte, sondern erwirbt Begriffe [Așadar, în cazul învățării unei limbi străine este necesar ca în propria minte să se delimiteze sfere cu totul noi la nivel conceptual: astfel, apar sfere de conținut care nu erau încă. Prin urmare, nu se învață doar cuvinte, ci se achiziționează conținuturi]. (Arthur Schopenhauer, Sämtliche Werke, Reclam, Band 5, p. 599, apud Reuning, 1973, p. 257)

Observațiile făcute de Reuning și Schopenhauer sînt corecte, însă din comentariile lui Reuning nu se evidențiază o distincție clară și necesară în discuția despre discontinuitatea realității lingvistice (germ. die sprachliche Welt).

Bazîndu-se pe ideile lui Humboldt, Trier consideră că există o continuitate a lumii lingvistice pentru vorbitori și că această continuitate constă în organizarea lexicului în cîmpuri:

Das Seinsbild einer Sprache ist ein Kontinuum, es enthält keine Lücken und blinden Flecke für den Sprachgenossen (s.n.) [Imaginea realităţii unei limbi este un continuum, ea nu conține goluri sau pete oarbe pentru vorbitori (s.n.)]. (Trier, 1934, p. 429)

Însă discontinuitatea cîmpurilor nu implică în mod obligatoriu discontinuitatea realității lingvistice. De exemplu, dacă limba română nu are termeni diferiți pentru 'unchi' și 'mătuşă’ pe linie maternă și pe linie paternă, acest lucru nu înseamnă că limba în întregul ei nu exprimă această distincție. Se poate vorbi numai despre o discontinuitate a lexicului, dar nu și despre o discontinuitate a limbii, ceea ce ne obligă să reconsiderăm argumentele aduse de Reuning, care nu diferențiază între limbă și lexicul unei limbi. Și în cazul exemplului privitor la lipsa cuvintelor pentru conceptul de 'inteligență pură în germana veche, și în comentariul lui Schopenhauer este vorba despre o altă realitate. Lipsa termenilor pentru inteligența pură’ în germana veche se poate explica în două moduri: fie conceptul exista deja, fără să fie lexicalizat, fie, deși puțin probabil, conceptul nu exista încă. În ambele cazuri nu poate fi vorba despre o discontinuitate a lumii lingvistice. Primul caz corespunde exemplului de mai sus privind lexicalizarea conceptului 'pantof cu toc înalt' în germană prin Stöckelschub și nelexicalizarea lui în limba română. Cel de-al doilea caz corespunde

${ }^{5}$ Vezi și Schwarz (1973, p. 430-433). 
situației descrise de Schopenhauer în situația învățării unei limbi străine, adică operarea de noi distincții la nivelul realității lingvistice, ceea ce corespunde teoriei lui Trier despre complex / bloc conceptual sau sferă conceptuală și cîmp lexical. În concepția lui Trier, un cîmp lexical este reprezentarea lingvistică articulată a unui bloc conceptual nearticulat. Analiza unui cîmp lexical presupune urmărirea modului de articulare a acestor sfere conceptuale. Așadar, lexicalizarea unei noi distincții sau a unei distincții mai vechi, dar nelexicalizate pînă atunci, este însăși dovada existenței cîmpurilor lexicale. Ceea ce ar fi trebuit, așadar, să observe Reuning este faptul că nu toate conceptele au un corespondent la nivelul lexical al limbii.

În aproximativ același fel se poate vorbi și despre neutralizările din planul lexical ale unor distincții existente în planul conceptual. Wartburg (1946, p. 141-142) prezintă cazul distincției în plan lexical dintre linia maternă și linia paternă pentru conceptele de 'unchi' și 'mătuşă' în limba latină, distincție care nu s-a păstrat în lexicul nici unei limbi romanice. Pentru conceptele 'unchi' și 'mătuşă limba română nu mai face distincție între linia maternă și linia paternă, astfel că pentru lat. avunculus 'unchi pe linia maternă' și patruus 'unchi pe linia paternă limba română are doar unchi, iar pentru lat. matertera 'mătuşă pe linia maternă’ și amita 'mătușă pe linia paternă’ limba română are doar mătuşă. Aceeași situație poate fi întîlnită și în istoria individuală a unei limbi. De exemplu, în limba română premodernă a funcționat o distincție diferită în cazul raportului opozitiv vechi - bătrîn: bătrîn a funcționat ca arhilexem pentru vechi. Ca și astăzi, vechi se referea la tot ce este inanimat ${ }^{6}$, însă bătrîn se referea la orice realitate (astăzi doar pentru tot ce este animat). Acest fapt este confirmat în documentele vechi și păstrat în cîteva sintagme toponimice precum Măgura Bătrînă (la est de Cîmpulung Moldovenesc, județul Suceava), Plaiul Bătrîn (la vest de Boboiești, județul Neamț), Jijia Bătrînă (afluent al rîului Jijia) sau Jiul Bătrîn (baltă în județul Dolj). În secolul al XVII-lea și la începutul celui de-al XVIII-lea, distincția menționată mai sus nu se stabilise încă, aşa cum arată documentele din această perioadă.

Nelexicalizarea unor concepte lexicalizate în altă limbă sau în aceeași limbă în stadii diferite nu presupune o discontinuitate a limbii. Ceea ce nu este conceptualizat încă, așa cum este cazul expus de Schopenhauer sau al cuvintelor pentru 'inteligența pură' în germana veche, nu presupune o discontinuitate a realității lingvistice. Despre o discontinuitate a limbii la nivel general nu se poate vorbi, deoarece tot ce a devenit accesibil cunoașterii raționale poate fi exprimat prin limbă, chiar dacă nivelul expresiei poate varia de la afix la frază și text. Se poate vorbi despre o discontinuitate existentă la nivelul lexical al limbii, deoarece nu toate conceptele individuale exprimate prin limbă sînt exprimate printr-un lexem. Între elementele componente ale cîmpului lexical ,încălțăminte” din limba română intră un număr destul de mare de cuvinte (pantof, cizmă, opincă, mocasin, gheată, bocanc, cipic, sanda etc.), însă acestea nu acoperă întreaga gamă de încălțăminte cunoscută vorbitorului de limba română. De exemplu, nu există lexeme individuale prin care să se marcheze distincția / fără toc/ - /cu toc/ sau / fără toc/ - /cu toc/ - /cu toc înalt/, pentru astfel de situații folosindu-se sintagme precum „cizme fără toc”, „cizme cu toc”, „cizme cu toc înalt" etc.

Distincția între nivelul conceptual, extralingvistic, nivelul lingvistic general și nivelul lexical nu poate fi ignorată într-o astfel de analiză. Primele două pot fi considerate paralele, în sensul că orice concept poate fi exprimat prin limbă, însă cel de-al treilea nivel, cel lexical, nu este decît o parte a nivelului lingvistic. Trebuie specificat faptul că nivelul conceptual nu este simetric cu nivelul lingvistic. Există un paralelism, în sensul că limba reflectă conceptele, însă nu în mod complet, deoarece într-un concept pot intra și trăsături nelingvistice, care provin din alte tipuri de cunoaștere (psihologică, tactilă etc.) decît cea lingvistică. Pe acest paralelism se bazează Trier (1973, p. 1, vezi supra, nota 3), atunci cînd vorbește despre cîmpuri conceptuale („Begriffsfelder”) și cîmpuri lexicale („Wortfelder”). Cîmpul conceptual este reprezentarea organizată prin limbă a unui bloc conceptual („Begriffsblock”) nearticulat în afara limbii. Măsura în care limba operează distincții în conținutul acestui bloc conceptual nu are nici o relevanță în ceea ce privește continuitatea realităţii lingvistice. Ceea ce nu este diferențiat în interiorul unui bloc semantic nu lipsește, ci există într-o stare latentă și nediferențiat într-un concept mai larg. Dacă diferen-

\footnotetext{
${ }^{6}$ Sintagma „țuică bătrînă” reflectă această realitate mai veche.
} 
țierea este făcută în planul general al limbii, și nu printr-un lexem specializat, cîmpul lexical nu poate fi considerat discontinuu în cazul în care acesta acoperă întreaga arie semantică a unui bloc conceptual prin elementele ce-l compun la un nivel mai general (vezi exemplul wîsheit - kunst - list la Trier, 1973). Aceste discontinuități sînt percepute ca atare numai în cazul unor disimetrii în organizarea unui cîmp, așa cum este cazul cîmpului „vehicul” în limba română, unde nu există cuvinte care să desemneze, de exemplu, clasa vehiculelor cu două roți și clasa vehiculelor cu patru roți sau și cu un alt număr de roți. Ceea ce nu este diferențiat în limbă sau a fost diferențiat la nivel lexical și s-a neutralizat (vezi exemplul rom. unchi - mătuşă, situație identică și în celelalte limbi romanice) nu poate fi considerat drept o discontinuitate la nivel lexical și, prin urmare, nici la nivelul cîmpului lexical. În rom. unchi se află întreg conținutul lat. avunculus și patruus, iar în rom. mătuşă întreg conținutul lat. matertera și amita. În realitate, nu este vorba despre o discontinuitate, ci numai despre o nediferențiere (sau o subdiferențiere) la nivelul lexical al limbii române, situație rezolvată prin folosirea sintagmelor „unchi din partea tatei”, „unchi din partea mamei" etc.

Uneori, teoria cîmpurilor lexicale este privită doar prin prisma posibilităţii delimitării clare a conținutului semantic al fiecărui element privit în afara cîmpului lexical, adică tocmai ceea ce teoria cîmpului lexical își propune să facă prin situarea fiecărui cuvînt în raport cu celelalte cuvinte cu care intră în aceeași sferă semantică. Observațiile privesc în mod special cazul polisemiei și cel al sinonimiei, uneori și al sensurilor metaforice, situații în care un cuvînt pare a fi dificil de încadrat într-o anumită sferă semantică. Definirea conținutului semantic al cuvîntului a fost abordată de mai mulți autori, fie dintr-o perspectivă generală asupra lexicului (Funke, 1954; Haller, 1963), fie cu trimitere directă la teoria cîmpurilor lexicale (Reuning, 1973; Müller, 1957), însă fără a se propune o soluție care să fie aplicabilă în teoria cîmpurilor lexicale. Soluția în cazul cuvintelor omonime și al celor polisemantice este cea propusă de G. Kandler, care consideră că un cuvint polisemic trebuie tratat la fel ca un cuvînt omonim și că, asemenea omonimelor, fiecare accepție a unui cuvînt polisemic reprezintă un element al unui cîmp lexical diferit. Kandler (1973, p. 360-362) dă două exemple: germ. Bank [bancă], pentru omonimie (/pentru a ședea/ - /instituție financiară/), și germ. Fleisch [carne], pentru polisemie (/parte a corpului/ - /aliment/).

Demersurile lexicologilor germani pentru elaborarea unei teorii coerente a cîmpurilor lexicale ar $\mathrm{fi}$ avut premisa unor soluții concrete o dată cu apariția lucrării Preliminarii la o teorie a limbii a lui Hjelmslev (1967), însă distincțiile sale au fost la început ignorate, dar exploatate fructuos mai tîrziu de Coseriu (vezi și infra). Prin observația că planul conținutului și planul expresiei prezintă o a doua dihotomie, și anume formă - substanță, şi că studiul limbii are în vedere acest aspect dublu al formei, problema polisemiei și a sinonimiei aduce în prim plan raportul dintre forma conținutului lexical și forma expresiei lexicale. Nici lucrările de semantică imediat următoare nu preiau această distincție. Ullmann (1975) nu amintește opera lingvistului danez. Abia mai tîrziu, Greimas (1966, p. 25-26) introduce această distincție în analiza semică și îşi elaborează lucrarea pe baza unei alte contribuţii a lui Hjelmslev (1971). Posibilitatea descrierii lexemelor prin seme va avea o influență decisivă în domeniul cîmpurilor lexicale, deoarece prezintă avantajul unei situări mai exacte în interiorul cimpului lexical pentru fiecare element al său. Hjelmslev consideră că fără o semantică structurală lexicologia se mărginește doar la o enumerare și niște definiții ale cuvintelor, adică, în realitate, o lexicografie:

A première vue, le vocabulaire reste capricieux et juste le contraire d'une structure. C'est pourquoi tout essai pour établir une description structurale du vocabulaire, et, à plus forte raison, une sémantique structurale, semble être voué à l'échec et devient facilement la proie du scepticisme. C'est aussi pourquoi la lexicologie reste une case vide dans la systématique de notre science, et qu'elle se réduit forcément à n'être qu'une lexicographie, ou simple énumération d'un effectif instable et indécis de certaines grandeurs mal définies auxquelles on attribue un fatras inextricable de multiples emplois différents et apparemment arbitraires [La o primă vedere, vocabularul rămîne capricios și exact contrariul unei structuri. De aceea, orice încercare de a stabili o descriere structurală a vocabularului și, cu atît mai mult, o semantică structurală, pare să fie sortită eșecului 
și devine uşor pradă scepticismului. De aceea, lexicologia rămîne o căsuță goală în sistematica științei noastre și este constrînsă să se limiteze la o lexicografie sau la o simplă enumerare a unui efectiv instabil și nesigur constituit din anumite mărimi prost definite, cărora li se atribuie o mulțime confuză de numeroase uzuri, diverse și aparent arbitrare]. (Hjelmslev, 1971, p. 106107)

Prin descrierea semantică într-un mod concret (prin trăsături semantice) a cuvintelor (lexemelor) se evidenţiază raporturile existente între elementele unui cîmp şi, de asemenea, sensul cu care acestea intră în respectivul cîmp. Însă descrierea este doar aparent concretă (fără raportare la alte lexeme), deoarece cuvintele rămîn unități discrete, adică se definesc doar în raport cu lexemele cu care împart o semnificație comună. Trăsăturile semantice conferă un aparent statut de individualitate concretă unui cuvînt, însă ele sînt rezultatul raportării la cuvintul/ cuvintele cu care au o trăsătură comună (atît în ceea ce privește trăsăturile comune, cît și în ceea ce privește trăsăturile distinctive) și una sau mai multe trăsături care se opun (trăsăturile distinctive). Principiul fundamental al definirii semantice a cuvintelor rămîne cel de la baza primelor teoretizări ale cîmpului lexical. Chiar dacă faza următoare a teoretizării cîmpurilor lexicale se bazează pe fonologia lui Trubetzkoy (1977, p. 60-80), aceasta nu poate fi privită separat de studiile lexicologilor germani din a doua treime a secolului trecut, care nu se diferențiază principial de fonologie, disciplină care descrie tot unităţi discrete. Negarea posibilităţii unui lexic complet organizat și observarea discontinuității unor cîmpuri lexicale sînt decisive în delimitarea cercetărilor în această direcție, fapt indicat și prin definirea conceptului de 'cîmp lexical' la Coseriu:

Un champ lexical est une structure paradigmatique constituée par des unités lexicales se partageant une zone de signification commune et se trouvant en opposition immédiate les unes avec les autres [Un cîmp lexical este o structură paradigmatică constituită din unități lexicale ce împart o zonă de semnificație comună și aflîndu-se în opoziție imediată unele cu celelalalte]. (Coseriu, 2001, p. 321)

Definiția este îmbunătățită ulterior prin adăugarea precizării „partageant une zone de signification continue (s.n.) commune [împărțind o zonă de semnificație continuă (s.n.) comună]” (Coseriu, 2001, p. 385), deși se poate spune că trăsătura continuităţii zonei de semnificaţie se poate deduce din sintagma „se trouvant en opposition immédiate les unes avec les autres” din prima definiție.

\section{Concluzii}

Observațiile lexicologilor germani din a doua treime a secolului al XX-lea în cadrul contribuțiilor privind conceptul de 'cîmp lexical' au condus la o perspectivă mai adecvată asupra lexicului şi au influențat în mod evident cercetările ulterioare. Ideea că lexicul unei limbi are o organizare internă complexă și completă apare deja la Humboldt, iar primele încercări de a o demonstra apar în spațiul german, în a doua treime a secolului trecut. Prin analiza diacronică a cîmpurilor onomasiologice a fost probată interdependența la nivel semantic între termenii ce le constituie, ceea ce a devenit un argument solid pentru cercetările ulterioare pentru o teorie cît mai articulată a cîmpurilor lexicale. Ipoteza iniţială, că s-ar putea descoperi o întreagă rețea structurală a lexicului unei limbi, nu a putut fi demonstrată, iar observațiile critice au avut în vedere chiar realizările parțiale, concretizate într-o primă teoretizare a cîmpurilor lexicale. O contribuție care trebuie pusă în evidență reiese din observațiile privind discontinuitatea cîmpurilor lexicale, ceea ce arată că statutul de realități discrete al lexemelor (adică prin raportare la alte lexeme) nu implică și limite comune între acestea, ci că pot exista și discontinuități la nivel de lexic. Cercetările ulterioare au asimilat observațiile critice privitoare la structurarea lexicului, fapt concretizat într-o abordare teoretică mai adecvată și, prin urmare, într-o cunoaștere mai aprofundată a lexicului unei limbi. 


\section{Bibliografie}

Bloomfield, L. (2005 [1935]). Language, Motilal Banarsidass Publishers, New Dehli.

Coseriu, E. (2001 [1968]). Les structures lexématiques, în L'Homme et son langage, Textes réunis par H. Dupuy-Engelhardt, J.-P. Durafour et F. Rastier, Éditions Peeters: Louvain - Paris - Sterling, Virginia, p. 315-331.

Funke, O. (1954). Form und Bedeutung in der Sprachstruktur, în „Sprachgeschichte und Wortbedeutung. Festschrift Albert Debrunner gewidmet von Schüllern, Freunden und Kollegen”, Franke Verlag, Bern, p. 141-150.

Greimas, A.-J. (1966). Sémantique structurale. Recherche de méthode, Moreau et Cie, Paris.

Kandler, G. (1973 [1959]). Die „Lücke” im sprachlichen Weltbild, în „Wortfeld-forschung. Zur Geschichte und Theorie des sprachlichen Feldes”, Hrsg. von Lothar Schmidt, Wissenschaftiche Buchgesellschaft, Darmstadt, p. 351-370.

Haller, R. (1963). Wörter, Bedeutungen, Begriffe, în „Sprache im technischen Zeitalter”, 8, p. 595-607.

Hjelmslev, L. (1967 [1943]). Preliminarii la o teorie a limbii, Traducere de D. Copceag, Centrul de Cercetări Fonetice și Dialectale, București.

Hjelmslev, L. (1971 [1957]). Pour une sémantique structurale, în „Essais linguistiques”, Minuit, Paris, p. 105-121.

Humboldt, W. von (2003 [1836]). Über die Verschiedenheit des menschlichen Sprachbaues und ihren Einfluss auf die geistige Entwiklung des Menschengeschlechts, în vol. Über die Verschiedenheit des menschlichen Sprachbaues und ihren Einfluss auf die geistige Entwiklung des Menschengeschlechts. Über die Sprache, Fourier Verlag, Wiesbaden.

Humboldt, W. von (2008). Despre diversitatea structurală a limbilor și influența ei asupra dezvoltării spirituale a umanității, Versiune românească, introducere, notă asupra traducerii, tabel cronologic, bibliografie și indici de Eugen Munteanu, Humanitas, București.

Locke, J. (1961 [1790]). Eseu asupra intelectului omenesc, vol. I-II, Traducere de Armand Roșu și Teodor Voiculescu, Editura Științifică, București.

Moscal, D. (2013). Teoria câmpurilor lexicale. Cu aplicație la terminologia populară a formelor de relief pozitiv, Editura Universităţii „Alexandru Ioan Cuza”, Iași.

Müller, G. (1957). Wortfeld und Sprachfeld, în „Beiträge zur Einheit von Bildung und Sprache im geistigen Sein. Festschrift zum 80. Geburtstag von Ernst Otto", Hrsg. von Gerhard Haselbach und Günter Hartmann, Walther de Gruyter \& Co., Berlin, p. $155-163$.

Reuning, K. (1973 [1941]). Die Feldtheorie, în „Wortfeldforschung. Zur Geschichte und Theorie des sprachlichen Feldes”, Hrsg. von Lothar Schmidt, Wissenschaftiche Buchgesellschaft, Darmstadt, p. 226-277.

Saussure, F. de (1922). Cours de linguistique générale, publié par Charles Bally et Albert Sechehaye avec la collaboration de Albert Riedlinger, Payot \& Cie, Paris.

Saussure, F. de (1998). Curs de lingvistică generală, Publicat de Charles Bally și Albert Sechehaye, în colaborare cu Albert Riedlinger, Ediție de Tullio de Mauro, Traducere și cuvînt înainte de Irina Izverna Tarabac, Polirom, Iași.

Schwarz, H. (1973 [1966]). Zwölf Thesen zur Feldtheorie, în „Wortfeldforschung. Zur Geschichte und Theorie des sprachlichen Feldes", Hrsg. von Lothar Schmidt, Wissenschaftiche Buchgesellschaft, Darmstadt, p. 426-435.

Trier, J. (1934). Das sprachliche Feld. Eine auseinandersetzung, în „Neue Jahrbücher für Wissenschaft und Jugendbildung”, 10, p. 429-449.

Trier, J. (1973 [1931]). Der deutsche Wortschatz im Sinnbezirk des Verstandes. Von den Anfängen bis zum Beginn des 13. Jahrhunderts, Zweite Auflage, Carl Winter Universitätsverlag, Heidelberg.

Trubetzkoy, N.S. (1977 [1939]). Grundzüge der Phonologie, Vandenhoeck \& Roprecht, Göttingen.

Ullmann, S. (1975). Précis de sémantique française, Éditions A. Franke S. A. Berne, Bern.

Wartburg, W.v. (1946). Problèmes et méthodes de la linguistique, PUF, Paris.

Weisgerber, L. (1962 [1950]). Die sprachliche Gestaltung der Welt, 3. neuarbeitete Auflage, Pädagogischer Verlag Schwann, Düsseldorf.

Weisgerber, L. (1973 [1939]). Vom inhaltlichen Aufbau des deutschen Wortschatzes, în „Wortfeldforschung. Zur Geschichte und Theorie des sprachlichen Feldes", Hrsg. von Lothar Schmidt, Wissenschaftiche Buchgesellschaft, Darmstadt, p. 193-225. 